Meta

Journal des traducteurs

Translators' Journal

\title{
On Language, Translation and Comparative Stylistics
}

\section{Hafedh Brini}

Volume 45, numéro 3, septembre 2000

La traduction dans le monde arabe

URI : https://id.erudit.org/iderudit/002143ar

DOI : https://doi.org/10.7202/002143ar

Aller au sommaire du numéro

Éditeur(s)

Les Presses de l'Université de Montréal

ISSN

0026-0452 (imprimé)

1492-1421 (numérique)

Découvrir la revue

Citer cet article

Brini, H. (2000). On Language, Translation and Comparative Stylistics. Meta, 45(3), 491-496. https://doi.org/10.7202/002143ar

\section{Résumé de l'article}

Le but de cette étude est de démontrer les rapports complexes entre les trois composantes : langue, traduction et stylistique comparée. Ces différentes matières ne devraient pas être confondues; elles devraient plutôt être conçues et organisées compte tenu de leurs buts respectifs et de leurs objectifs collectifs, conformément aux progrès réalisés dans ce domaine. d'utilisation que vous pouvez consulter en ligne.

https://apropos.erudit.org/fr/usagers/politique-dutilisation/ 


\title{
On Language, Translation and Comparative Stylistics
}

\author{
HAFEDH BRINI \\ Institut supérieur des langues, Tunis, Tunisie
}

\section{RÉSUMÉ}

Le but de cette étude est de démontrer les rapports complexes entre les trois composantes: langue, traduction et stylistique comparée. Ces différentes matières ne devraient pas être confondues; elles devraient plutôt être conçues et organisées compte tenu de leurs buts respectifs et de leurs objectifs collectifs, conformément aux progrès réalisés dans ce domaine.

\begin{abstract} keep pace with the progress made in these fields.

\section{MOTS-CLÉS/KEYWORDS}

interpreting, transcoding, cognitive, contrastive, communicative
\end{abstract}

This paper aims to show the complex relations between three components: language, translation and comparative stylistics in a context of teaching foreign languages. These different subjects should not be confused; they should rather be designed and organized according to their individual aims as well as their collective objectives, so that we may

\section{Introduction}

Teaching foreign languages gives rise to pedagogical and theoretical problems that need to be solved to ensure continuous improvement of the ways of teaching, a better acquisition of language as well as knowledge by the students, and to enhance scientific research in this field.

Students learning English as a foreign language, for instance, encounter various difficulties. In addition to language per se, such as reading and writing skills, they are taught civilization and culture studies and are expected to develop personal opinions and attitudes in these matters. They are also taught translation from English into their mother tongue - Arabic - and vice versa; later on, they should take other courses such as translation theory and comparative stylistics.

The curriculum of the English Master's being so comprehensive and diverse, difficulties do exist either on the part of the student or the teacher. As for the student, his learning is often slow and his writing skill is usually below his reading, mainly because of a neglect of reading, a lack of reading methodology, or a failure to find the connections between different subjects, enabling better exploration of interchangeable data, ideas, expressions or formulations. In fact, aren't students' shortcomings in writing linked to their reading problems? As translation unveils students' problems in the comprehension of English texts, the course should help them to acquire a good methodology in reading and understanding texts by stimulating conscious and organized efforts. 
Translation theory being at an early stage of development at the Arab level, scholars and teachers conceive translation differently. They also hold opposing views on translation theory and some even consider that comparative stylistics is simply translation.

Drawing on the significant progress which is occurring in the West in these branches of knowledge and on personal experience in teaching translation theory as well as practice and research, I'll try in this paper to dismantle the complex web linking the three components: language, translation and comparative stylistics.

\section{Language and translation}

\section{Language vs speech acts}

One of the major issues that should be given careful consideration in teaching English in an ELF context is the distinction between language and texts. In fact, linguistic signs in any language are polysemous as they hold different significations depending on whether they are used in a specific text or out of context.

Undergraduate students in particular tend to identify words with their most potential meanings, ie their basic meanings. But while progressing in studying language in various contexts and situations, they continuously discover that the meaning of words and expressions is not so stable. It is only through hard work that they may become aware of the fact that learning a foreign language is a hard endeavor involving the acquisition of arbitrary and institutionalized differences.

When we move to another language, ideas are arranged and produced differently. To learn a foreign language is to make a trip to other habits, other forms of thought and expression. The road is uneven and progress uncertain, since learning "requires much initial submission" (Guénot 1971: 115) and builds up gradually as the process organization is carried out.

To know a language is first and foremost to comprehend it; to comprehend is to perceive and to perceive is to articulate. The more you perceive a language, the better you speak it, and to speak it helps to perceive it... "As to meaning, it is felt before being defined, attributed before being fixed" (Guénot 1971: 186).

Learners who persevere in this endeavor are really conscious of the distinction between language and speech acts, while those who make the least effort and content themselves with a minimum, delude themselves into believing that they have mastered a foreign language. In brief, speech acts make language unlimited and our knowledge of it always relative.

\section{Translation vs linguistic interference}

Linguistic interference occurs whenever a bilingual person uses in either language a characteristic or a feature that is specific to the other language. So, linguistic interference is usually produced spontaneously by the inevitable coexistence of two or three different languages, especially among beginners. However, when teachers notice this kind of error in the students' writing, which is obviously due to interference from Arabic or French, they very often call it "translation." So, it is worthwhile to stress the distinction between linguistic interference as a non deliberate phenomenon leading 
to a misleading "translation" or "transcoding," on the one hand, and translation as a linguistic and cognitive exercise revolving around interpretation and stimulating conscious and organized efforts for a better command of English, on the other hand.

Some people might argue that this question of terminology does not matter; yet, we are convinced that it makes all the difference, since terms, which are used to express concepts, do not convey the same meaning to everybody as long as they are not clearly and precisely defined.

Moreover, we strongly believe that the standardization of terminology in human sciences can only improve understanding between teachers of different subjects and enhance collaboration and interdisciplinary research.

Students can also benefit from this terminological issue. As far as a translation course is concerned, students are initially sensitized to the connection of the course with other courses, especially reading and writing. In addition to the prevailing notion of translation, pertaining to the transmission of the author's thought from one language to another, students are acquainted with an equally important acceptance of the process. It is translation in the same language, ie to express something in a different, especially more concrete form, to judge or guess that something has the specified meaning or intention.

Students are also invited to consult dictionaries to check the existence of this second meaning in the three main languages they know: Arabic, English and French. It is a simple way to explain to them that translation is embedded in any act of communication, either in the same language or from one language to another, and that a translation course is quite a remedy for linguistic interference.

\section{The contribution of translation to language teaching}

A translation course aims at helping students to acquire an efficient method in the comprehension of texts, in order to translate them correctly into another language. In fact, pedagogical translation consolidates the students' ability to analyze texts in a functional way enabling them to pinpoint the intended meaning, to acquaint themselves with their shortcomings or linguistic and cognitive problems, and acquire a good methodology in dealing with such matters as word polysemy, context consideration, dictionary consultation, language genius and usage...

Translation is overall a means of measure and check that helps students to acquire a suitable degree of flexibility and accuracy in both comprehension and expression.

\section{Translation theory}

Given the communicative nature of translation, translation theory involves the general principles that organize the procedure and explains the mental processes enabling the transfer of a text content from one language to another. It also covers the most important issues raised in the field of translation, such as fidelity, the problem of untranslatability, the relationship between translation and proximate disciplines such as comparative stylistics, linguistics and terminology. 


\section{Language and comparative stylistics}

\section{The objective of comparative stylistics}

The objective of comparative stylistics is to study the stylistic characteristics of one language in comparison with those of another one. This systematic study offers students a better and deeper knowledge of the features that distinguish one language from another.

Examples:

- To become penniless /aflasa/

- The Arabs have pioneered in many branches of science /kâna lilcarabi assabaqu fi:

Sattâ furuci al macrifati/

These are two cases of "transposition."

In the first example, the verb /aflasa/ is expressed by a phrase in English, while in the second example the verb "to pioneer" is replaced with a noun /assabaqu/ in Arabic.

- He was blown away /dhahaba adrâja arriyâhi/

This is a case of "modulation," where each language describes the situation from a different viewpoint. While English indicates the means (blown), Arabic does the opposite: the result first /dhahaba/, then the means /adrâja arriyâhi/. Thus, we have a "chassé-croisé":

Means: blown/adrâja arriyâhi/

Result: /dhahaba/ away

- Give a pint of your blood /tabarra ${ }^{c}$ biqali:lin min damika/

- Before you could say Jack Robinson /fi: tarfati cayn/

These are two cases of "equivalence" where two languages describe the same situation by using quite different structural and stylistic means. In the first example, the expression "to give a pint," "pint" being a unit of measure for liquids equal to about half a liter, is rendered into Arabic by the equivalent /tabarra ${ }^{c}$ biqali:lin min/ which literally means "donate some of."

In the second example, the English idiom "before you could say Jack Robinson," which means "very quickly or suddenly," has an equivalent idiom in Arabic/Fi tarfati cayn/ which means "in the twinkling of an eye."

\section{The scope and limits of comparative stylistics}

According to Vinay and Darbelnet (1977), the three above-mentioned cases - transposition, modulation and equivalence - in addition to four others, which are borrowing, tracing ("calque"), literal translation and adaptation, constitute the seven techniques of translation. The authors of the book "Stylistique comparée du français et de l'anglais" even consider comparative stylistics as a method of translation (notice the expression, "méthode de traduction," they put under the title on the first page).

It is undeniable that comparative stylistics is beneficial to students, since it enables them to identify the characteristics which distinguish their mother language from a foreign one, and hence to perceive the phenomena that endow each language 
with a peculiar genius. Yet, it is arguable that comparative stylistics can explain the process of translation or set forth "laws valid to the two languages concerned" (Vinay and Darbelnet 1977: 20).

Since the comparison of two languages requires primarily the performance of translation, we can assert that comparative stylistics is subsequent to translation and not prior to it. Therefore, the seven techniques are no more than means of comparison.

If we reconsider the example "he was blown away," it appears that, to translate it into Arabic, one would immediately look for its functional equivalent rather than think of the "technique" to be used, whether it is transposition, modulation or equivalence... As a matter of fact, if the translator fails to find the appropriate equivalent in Arabic, /dhahaba adrâja arriyâhi/, it will be useless to know that this kind of transfer is called "modulation" from a comparative viewpoint. The same thing applies, of course, to the other techniques offered by comparative stylistics.

Moreover, comparative stylistics usually suggests only one equivalent among several possible equivalents of a lexical unit or expression. In the previous example, we can say in Arabic: /dhahaba adrâja arriyâhi/ as well as /'casafat bihi arriyâhu/ or /huwa fi: mahabbi arri:hi/, all of which are expressions with the same meaning.

Finally, it appears that comparative stylistics, which is mainly interested in establishing correspondences and equivalences in two languages, does not go beyond the limit of language as a whole to reach the mobility of speech and usage.

Hence, it can neither foretell the most appropriate equivalents for expressions in context nor embrace all potential cases of translation within the ever-renewable act of communication. The field of translation is indeed far from being limited or confined to linguistic facts, idiomatic expressions or correspondences that may constitute the subject of a comparative study.

\section{Conclusion}

It seems that "language" is an ambiguous notion holding a good many paradoxes. Though it is naturally polysemous, it is being standardized in the various fields of science; while it is unlimited because it is ceaselessly enriched by usage and speech acts, one cannot draw on it to explain every linguistic process. It is our failure to encompass it that generates such limits...

But at least one way out presents itself. Because language learning necessarily involves several courses such as translation, translation theory and comparative stylistics, these different subjects should not be confused; we should rather design and organize them according to their individual aims as well as their collective objectives, so that they contribute efficiently to the improvement of the students' learning of English as well as to the broadening of their overall knowledge.

In this paper, we have mainly explained that the function of comparative stylistics is contrastive while that of translation theory and practice is communicative.

\section{REFERENCES}

Arab League Educational Cultural and Scientific Organization (1989): Unified Dictionary of Linguistic Terms, Tunis.

Babel, International Journal of Translation, 4-1 (March, 1958).

Basnett, S. and A. Lefevre (1990): Translation, History and Culture, London and New York, Pinter Publishers. 
BeLl, R. T. (1993): Translation and Translating: Theory and Practice, London and New York, Longman.

BRINI, H. (1996): review of Vinay and Darbelnet's Stylistique comparée du français et de l'anglais (in Arabic), Turjumân, Revue de Traduction et d'Interprétation, 5-1 (avril 1996), pp. 33-45.

— (1998c): "Les problèmes terminologiques dans la traduction arabe," Turjumân, 7-2 (octobre 1998), special issue "Terminologie: Nouvelles perspectives," pp. 87-111.

— (1999): "The Single Nature of Translation: One General Functional Theory for Several Aspects of Practice," Turjumân, 8-1 (avril 1999), pp. 23-36.

- (1998a): La méthodologie de la traduction chez Mohamed Yalaoui (in Arabic), "Mabahith Jamiciya 2,” Tunis, Dar El Khidmât El Amma Linnachr, pp. 97-126.

— (1990): "La traduction dans la polémique des différences entre les langues et les cultures" (in Arabic), Revue Tunisienne des Langues Vivantes, 5, pp. 21-39. (Acts of the Congress organized by the Département des Langues on May 4th-5th, 1990).

- (1998b): "La notion de sens en traduction" (in Arabic), Annales de l'I.B.L.V., 3, pp. 51-61.

Delisle, J. (1980): L'analyse du discours comme méthode de traduction, Ottawa, Éditions de l'Université d'Ottawa.

Guénot, J. (1971): Clefs pour les langues vivantes, Paris, Seghers.

Hatim, B. et I. Mason (1993): Discourse and the Translator, London and New York, Longman.

Khalaili, K. (1994): A Gem Dictionary of Comparative Proverbs - English - Arabic - French Latin, Beyrut, Librairie du Liban Publishers.

Kilani, T. and N. Ashour (1991): A Dictionary of Proverbs, English-Arabic, Beyrut, Librairie du Liban.

Meta, Journal des Traducteurs, 25-1 (mars 1980), special issue "La documentation," Montréal, Presses de l'Université de Montréal.

Mubarak, M. (1995): Dictionary of Linguistic Terms, French-English-Arabic, Beyrut, Dar Al Fikr Allubnani.

Newmark, P. (1988a): Approaches to Translation, Prentice Hall International.

- (1988b): A Textbook of Translation, Prentice Hall International.

Seleskovitch, D. and M. Lederer (1986): Interpréter pour traduire, Paris, Publications de la Sorbonne, Didier Érudition.

Steiner, G. (1978): Après Babel, une poétique du dire et de la traduction, Paris, Albin Michel.

Traduire, Revue française de traduction, 134 (December, 1987/IV. S.F.T. 1947-1987, Congress "Apprendre et comprendre: Soucis constants du traducteur").

Vinay, J.-P. and J. Darbelnet (1977): Stylistique comparée du français et de l'anglais, Paris, Didier. 